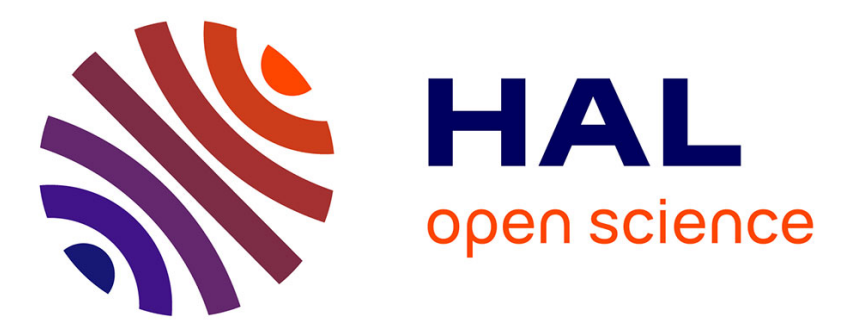

\title{
Acetals from primary alcohols with the use of tridentate proton responsive phosphinepyridonate iridium catalysts
}

Apurba R. Sahoo, F. Jiang, Christian Bruneau, G.V.M. Sharma, S. Suresh, Mathieu Achard

\section{- To cite this version:}

Apurba R. Sahoo, F. Jiang, Christian Bruneau, G.V.M. Sharma, S. Suresh, et al.. Acetals from primary alcohols with the use of tridentate proton responsive phosphinepyridonate iridium catalysts. RSC Advances, 2016, 6 (102), pp.100554-100558. 10.1039/c6ra23946c . hal-01416442

HAL Id: hal-01416442

https://hal-univ-rennes1.archives-ouvertes.fr/hal-01416442

Submitted on 17 Feb 2017

HAL is a multi-disciplinary open access archive for the deposit and dissemination of scientific research documents, whether they are published or not. The documents may come from teaching and research institutions in France or abroad, or from public or private research centers.
L'archive ouverte pluridisciplinaire HAL, est destinée au dépôt et à la diffusion de documents scientifiques de niveau recherche, publiés ou non, émanant des établissements d'enseignement et de recherche français ou étrangers, des laboratoires publics ou privés. 


\title{
Acetals from Primary Alcohols with the Use of Tridentate Proton Responsive PhosphinePyridonate Iridium Catalysts
}

\author{
A. R. Sahoo, ${ }^{a}$ F. Jiang, ${ }^{a}$ C. Bruneau, ${ }^{a}$ G. V. M. Sharma, ${ }^{b}$ S. Suresh ${ }^{b}$ and M. Achard ${ }^{a} *$
}

\author{
* Corresponding authors \\ a UMR6226, Institut des Sciences Chimiques de Rennes, Université de Rennes1, OMC: Organometallics: Materials \\ and Catalysis, Campus de Beaulieu, 35042 Rennes Cedex, France \\ E-mail: mathieu.achard@univ-rennes1.fr \\ ${ }^{b}$ Organic and Biomolecular Chemistry Division, CSIR-IICT, Hyderabad-500007, India
}

The association of the new phosphinepyridonate ligands along with iridium metallic precursor resulted in the selective acetalization of various primary alcohols via a formal dehydrogenative coupling reaction.

Apart from being efficient protecting groups of carbonyl derivatives, ${ }^{[1]}$ acetals have also found applications in industry as building block for the production of thermoplastics and specific polymers, ${ }^{[2]}$ as flavouring and cosmetic agents, ${ }^{[3]}$ or fuel additives to lower emission of particles and NOx while preventing alteration of the octane and cetane rates. ${ }^{[4]}$. Traditional preparation of acetals involve reaction of the corresponding carbonyl derivatives with alcohols or diols in the presence of acidic additives. ${ }^{[5]}$ In situ generation of the carbonyl derivatives represents interesting alternative to such process. In this cascade transformation, the starting alcohol acts as a carbonyl source and as nucleophile with the generation of water as the only side product. Heterogeneous and homogeneous oxidative processes were reported for the production of acetals arising from short and long chain alcohols. ${ }^{[6-11]}$ Recent heterogeneous photocatalytic dehydrogenative coupling of low boiling point primary alcohols enabled the preparation of the corresponding acetals. ${ }^{[12]}$ Catalytic dehydrogenation has emerged as a promising alternative for the generation of carbonyl derivatives from alcohols. ${ }^{[13]}$ Thanks to finely tuned or non-innocent/proton responsive ligands resulting in the formation of metal-ligand or more recently metal-metal cooperative complexes, recent studies allowed the development of efficient acceptorless homogeneous catalytic systems. ${ }^{[14]}$ Depending on the nature of ligand, the presence of vacant sites on the metal, in the absence of any other reagent, catalytic dehydrogenation of primary alcohols can lead either to Guerbet type alcohol/ketone, ester or acetal. Pioneering report on dehydrogenative acetalization from primary alcohol was reported by Murahashi with the use of ruthenium or rhodium complexes yielding up to $20 \%$ of acetals. ${ }^{[15]} \mathrm{A}$ breakthrough came with the use of well-defined ruthenium complex featuring acridine pincer type ligands where the presence of proposed hemilabile ligands increased selectivity toward the acetal formation. ${ }^{[16]}$ Among the catalytic systems used in hydrogen transfers, hydroxypyridine/pyridone containing complexes operating through proposed bifunctional pathways have found interesting applications. $^{[17]}$ Noteworthy that non chelating phophinepyridones have also found broad applications in self-assembling catalytic systems. ${ }^{[18]}$ We recently reported the straightforward preparation of new five membered phosphinepyridone chelates and demonstrated the efficiency of such ligand in hydrogenation of unfunctionalized ketones. ${ }^{[19 a]}$ Based on our recent interest on hemiaminal

formation, ${ }^{[19 b]}$ the peculiar behaviour of such ligand in the presence of the bulky pentamethylcyclopentadienyl ligand expressing an hemilabile character of the pyridone moiety attracted our attention. Herein we report on the first preparation of tridentate phosphinepyridones and their applications in iridium-catalyzed acetalisation from various primary alcohols through acceptorless dehydrogenative condensation. Starting from unprotected 6-methyl-2-pyridone L1-H by simple treatment with two equivalents of base to generate the nucleophilic dianion followed by reaction with dichlorophosphine, we were 


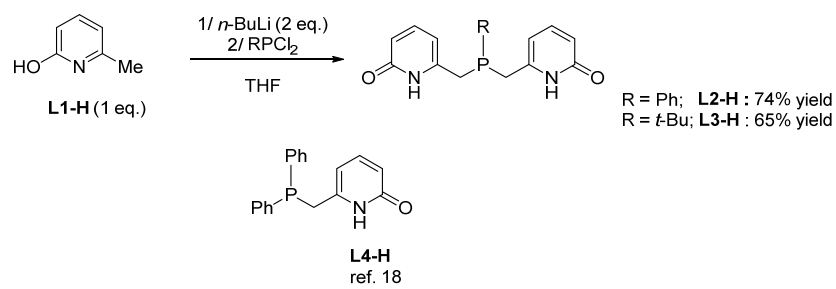

Scheme $\mathbf{1}$ Preparation of the new tridentate $\mathbf{L} \mathbf{2}-\mathbf{H}$ and $\mathbf{L} \mathbf{3}-\mathbf{H}$ ligands. Previously reported ligands $\mathbf{L} \mathbf{1}-\mathbf{H}$ and $\mathbf{L} \mathbf{4}-\mathbf{H}$ used in this study.

able to isolate the corresponding dialkyl- L2-H and trialkyl- phosphinepyridone $\mathbf{L} 3-\mathbf{H}$ after acidification in $\mathbf{7 4 \%}$ and $65 \%$ yield, respectively (Scheme 1). With these ligands in hand (Scheme 1), we evaluated their influence in acceptorless dehydrogenation of benzyl alcohol $\mathbf{2 a}$ in the presence of iridium precursors (Table 1). The reaction of benzyl alcohol $\mathbf{2 a}$ in the presence of $\left[\mathrm{Cp}^{*} \mid \mathrm{ICl}_{2}\right]_{2}$ as catalyst precursor led to the formation of the ether $\mathbf{3 a}$ and the aldehyde $\mathbf{4 a}$ in a $1: 1$ ratio with $51 \%$ conversion (entry 1 ). When $\left[\operatorname{Ir}\left(\mathrm{Cp}^{*}\right)\left(\mathrm{H}_{2} \mathrm{O}\right)_{3}\right] \mathrm{SO}_{4}$ was used as metallic precursor, full conversion of $\mathbf{2 a}$ and selective formation of the ether $\mathbf{3 a}$ were observed (entry 6). To the best of our knowledge, selective formation of ether in the presence of a simple iridium metallic precursor has not been reported. ${ }^{[20]}$ Even in a closed Schlenk system, addition of 6-methyl-2-pyridone L1-H confirmed the previous findings of Fujita and Yamaguchi with related ligands, which favored dehydrogenation and led to the major formation of benzaldehyde 4a along with the presence of almost equimolar amount of dibenzyl ether 3a (entry 2). ${ }^{[17 a-c, 21]}$ Unprecedentedly, the use of our previously reported chelating phosphinepyridonate $\mathbf{L} \mathbf{4}-\mathbf{H}$ reversed the selectivity in favor of the acetal reaching $\mathbf{3 4 \%}$ yield of $\mathbf{5 a}$ (entry 3). Further screening of the new ligands containing pyridonate moiety revealed a

Table 1 Acetalization versus Etherification from benzylacohol $\mathbf{2} \mathbf{a}^{a}$

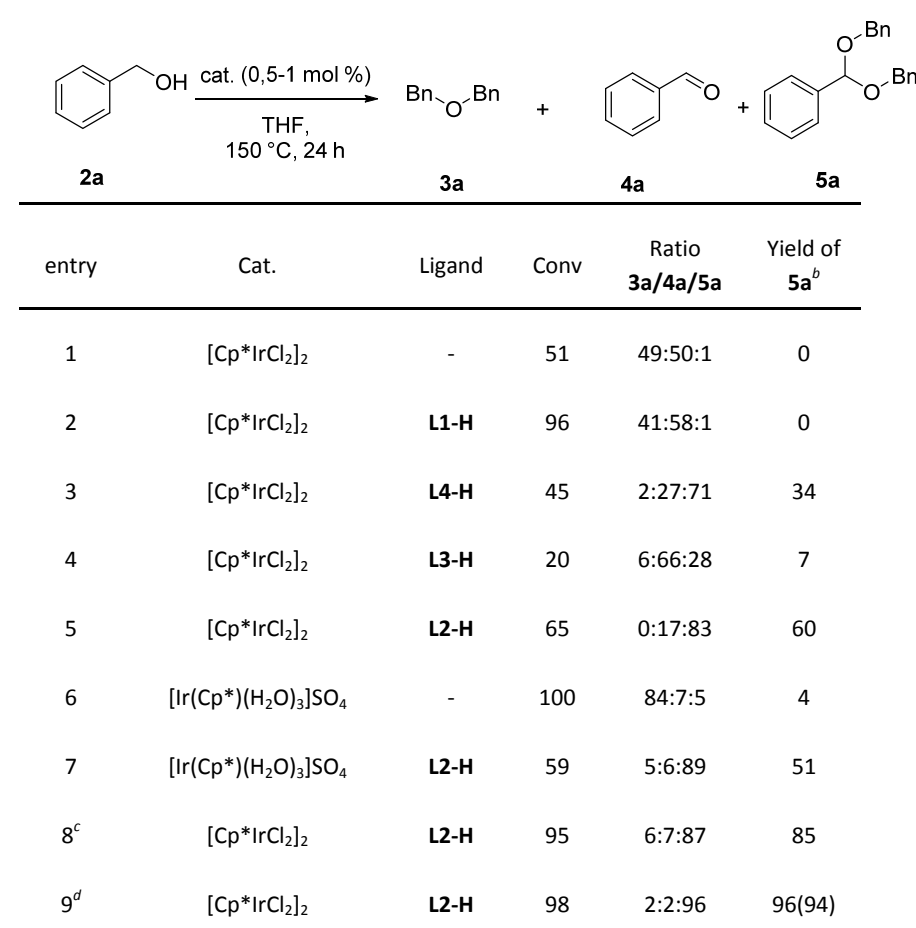

${ }^{a}$ Experimental conditions: all reactions were performed under an inert atmosphere of argon and carried out with benzyl alcohol 1a $(1.0 \mathrm{mmol})$, Ligand $(1 \mathrm{~mol} \%)$, metallic precursor (1 mol\% with respect to the metal) in a closed Schlenk tube in THF (1 mL) at 150 ${ }^{\circ} \mathrm{C}$ for $24 \mathrm{~h} .{ }^{b}$ Conversions and GC yields were determined by GC analysis with dodecane (30 $\mu \mathrm{L}$ ) as internal standard and the number in parenthesis corresponds to the isolated yield after purification by column chromatography. ${ }^{c}$ Reaction carried out with $0.5 \mathrm{~mL}$ of THF. ${ }^{d}$ Reaction carried out with $0.5 \mathrm{~mL}$ THF at $170{ }^{\circ} \mathrm{C}$ for 24 hours.

strong influence of the second pyridone moiety toward conversion and selectivity and the best result for acetalization has been obtained in the presence of $\mathbf{L 2 - H}$ and $\left[\mathrm{Cp}^{*} \mid \mathrm{IrCl}_{2}\right]_{2}$ or $\left[\operatorname{Ir}\left(\mathrm{Cp}^{*}\right)\left(\mathrm{H}_{2} \mathrm{O}\right)_{3}\right] \mathrm{SO}_{4}$ affording up to $60 \%$ GC yield of $\mathbf{5 a}$ along with benzaldehyde (entry 5 and 7). Finally increasing the reaction temperature in the same range as previous reports gave almost exclusively the acetal 5a in $98 \%$ GC yield and $94 \%$ isolated yield (entries 8 and 9). ${ }^{[15,16 a]}$ The use of the more basic trialkylphosphine L3-H dramatically lowered the conversion (entry 4). In all the above experiments, in the absence of additives, the formations of benzyl benzoate or hemiacetal were only observed as traces. Having established our best reactions toward the 
selective formation of acetal 5a from benzyl alcohol, we next investigated the scope of the transformation with various alcohols (Scheme 2). These results show that the catalytic system is active in dehydrogenative acetalization of various benzylic alcohols irrespective of the substitution on the

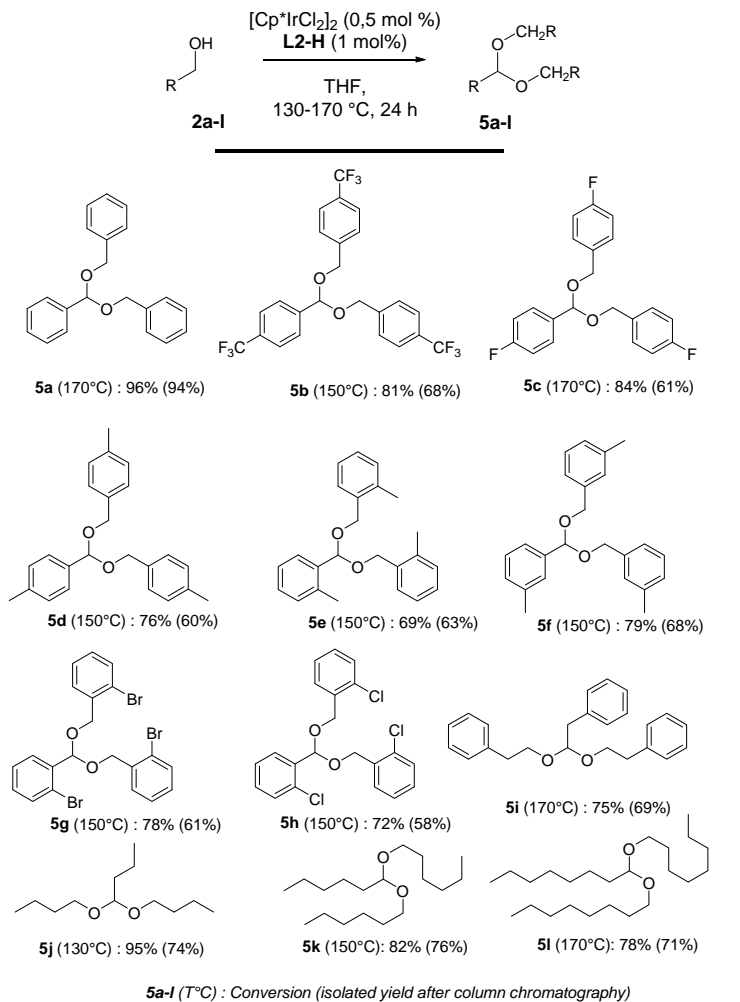

Scheme 2 Preparation of various acetals from aliphatic and benzylic alcohols

aromatic moiety affording almost up to $80 \%$ conversion in most cases with isolated yields ranging from 58 to $94 \%$ for acetals $\mathbf{5 a -}$ i. The modest to good isolated yields of acetals can be easily explained by their relative instability slow hydrolysis during purification by column chromatography. Selective formation of aliphatic acetals $\mathbf{5 j}$-I was also observed from butanol, hexanol and octanol giving acetals in up to $95 \%$ conversion and $76 \%$ isolated yield. Noteworthy that a $130^{\circ} \mathrm{C}$ reaction temperature was sufficient to ensure the conversion of butanol. The case of bulky primary benzylic alcohol was also investigated (Scheme 3 ). Although the reaction of 2-naphthylmethanol $\mathbf{2 m}$ under our optimized catalytic conditions did afford the expected acetal $\mathbf{5 m}$, the side formation of unexpected naphthalene $\mathbf{6 m}$ and 2-methylnaphthalene $\mathbf{7 m}$ was also detected. This result may in part be explained by the occurrence of side decarbonylation and formal hydrogenolysis processes. ${ }^{\text {[22-24] }}$ The competitive experiment between one equivalent of benzyl alcohol and one equivalent of 1,3-propanediol resulted in the formation of the expected cyclic acetal $\mathbf{5 n}$ in $35 \%$ conversion and $30 \%$ isolated yield indicating a deactivation of the catalytic system presumably due to the coordination and/or the decomposition of 1,3-propanediol (Scheme 4).

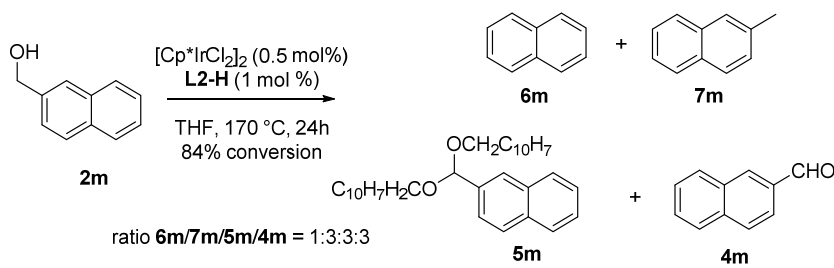

Scheme 3 The case of the bulky 2-naphthalenemethanol $2 \mathrm{~m}$ : Observation of decarbonylated and deoxygenated side products

Under these experimental conditions, secondary alcohols were selectively converted into the corresponding ketones (See supporting information). In order to get an idea of the exact nature of the active/resting species during the dehydrogenative acetalization, we investigated the fate of the ligand $\mathbf{L 2}-\mathbf{H}$ with $\left[\mathrm{Cp}^{*} \mid \mathrm{ICl}_{2}\right]_{2}$. Owing to its lower polarity, reaction of octanol $\mathbf{2 l}$ under typical catalytic reaction conditions resulted in $80 \%$ conversion of the starting primary alcohol to the corresponding acetal $\mathbf{5 I}$ along with the formation of a yellow/orange precipitate in the resulting mixture. ${ }^{31} \mathrm{P}$ and ${ }^{1} \mathrm{H} N \mathrm{NR}$ analyses of this latter highlighted the formation of two complexes including one symmetrical species based on ${ }^{1} \mathrm{H} N M R$ integration with a ${ }^{31} \mathrm{P}$ signal located at $31.5 \mathrm{ppm}$ and one unsymmetrical with a singlet at $13.2 \mathrm{ppm}$, respectively. ${ }^{[19 \mathrm{a}]}$ 


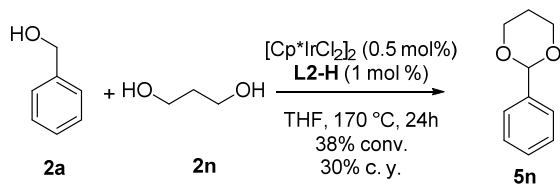

Scheme 4 Initial attempt to access to cyclic acetal

Next, in order to characterize the aforementioned species, the stoichiometric reaction of $\mathbf{L} \mathbf{1}-\mathbf{H}$ and $\left.\left[\mathrm{Cp}^{*} \mid \mathrm{ICl}\right]_{2}\right]_{2}$ was carried out in methanol at room temperature and resulted in the formation of a yellow solution. ${ }^{[19 a]}$ Owing to the presence of the bulky $\mathrm{Cp}^{*}$ ligand, NMR spectroscopic analysis revealed the presence of two species in dynamic equilibrium (Scheme 5). ${ }^{31} \mathrm{P} N M R$ analyses in $\mathrm{CD}_{3} \mathrm{OD}$ revealed the presence of two species located at 30.2 and $13.5 \mathrm{ppm}$, respectively, whereas the use of $\mathrm{D}_{2} \mathrm{O}$ demonstrated the complete conversion toward the species located at $30.2 \mathrm{ppm}$. Evaporation and addition of $\mathrm{CD}_{3} \mathrm{OD}$ restored the equilibrium. Monocationic complex Ir-1 was unambiguously identified by successful crystallization layering methanol and diethyl ether. NMR spectroscopy corroborates the formation of an unsymmetrical cationic iridium(III) complex Ir-1 bearing a pendant pyridone arm. The structural dicationic isomer Ir-1' was easily deduced from our previous results and by comparison with a previously reported iridium complex featuring a tridentate $\left(k^{3}, \mathrm{P}, \mathrm{O}, \mathrm{O}^{\prime}\right)$ phosphinephenolate $\mathrm{e}^{[19 \mathrm{a}, 25]}$ and suggests that the symmetrical species corresponding to Ir-1' located at $30.2 \mathrm{ppm}$ arises from the reversible coordination of the protonated side arm. The tridentate behaviour was further confirmed by deprotonation of Ir-1 in basic medium or by reaction of $\mathbf{L} 2-\mathbf{H}$ with $\left[\mathrm{Cp}^{*} \mid \mathrm{ICl}_{2}\right]_{2}$ leading to the exclusive formation of the sensitive

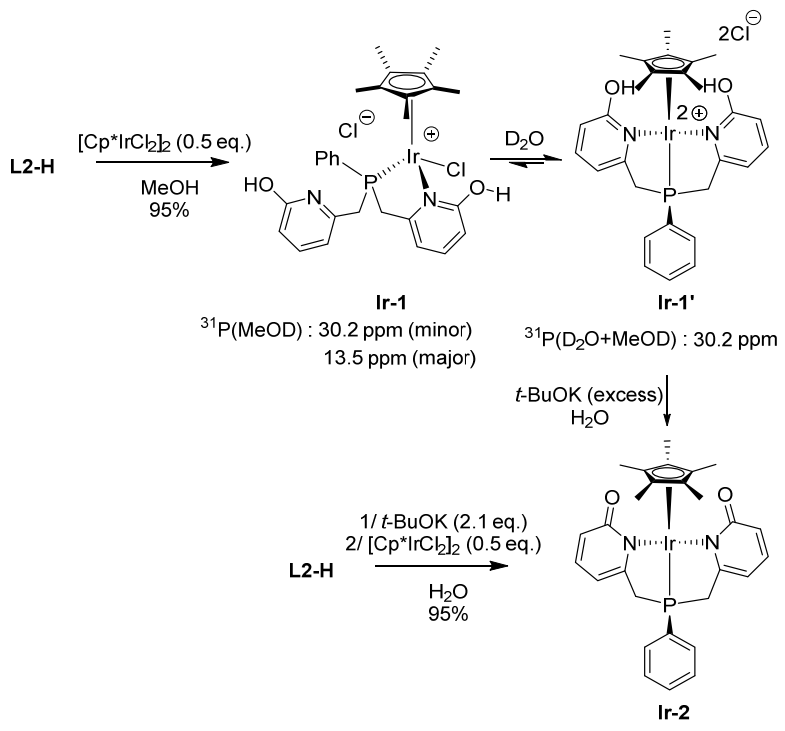

${ }^{31} \mathrm{P}\left(\mathrm{CD}_{2} \mathrm{Cl}_{2}\right): 27.0 \mathrm{ppm}$

Scheme 5 Dynamic behaviour of the well-defined iridium complex Ir-1.

complex Ir-2. With these complexes in hand, we next investigated their possible implication in the catalytic transformation. As expected deprotonated Ir-2 complex was

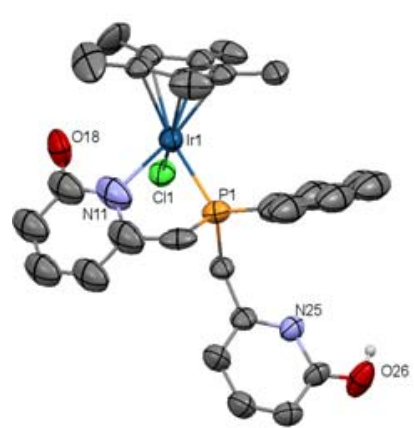

Fig. 1 X-ray structure of Ir-1. Selected bond lengths ( $\AA$ ) and angles $\left(^{\circ}\right)$, Ir1-Cl1 2.399(3); Ir1-P1 2.278(4); Ir1-N11 2.14(1); C12-O18 1.23(2); C24-O26 1.424(1); Cl1-Ir1-P1 91.4(1); Cl1-Ir1-N11 88.0(3); P1-Ir1-N11 79.6(3); N11-C12-O18 115(1); N25-C24O26 119(1). CCDC 1453002 contains the supplementary crystallographic data for Ir-1

found to be inactive in the aimed transformation during the reaction of benzyl alcohol 2a whereas the use of a catalytic amount of Ir-1/Ir-1' afforded the expected acetal 5a selectively suggesting the implication of Ir-1/Ir-1' in the catalytic transformation. ${ }^{\text {[16] }}$ 
However, at this stage of this research, considering the attractive but complex dynamic behaviour of phosphinepyridones, a metallo- organo-catalyzed transformation as well as the transient formation of bi- or poly-metallic species cannot totally be excluded. ${ }^{[18,19 a, 26]}$

\section{Conclusions}

In conclusion, we have reported the synthesis of two new tridentate proton responsive/hemilabile ligands allowing the development of a new catalytic system for the dehydrogenative acetalization of primary alcohols with the release of one molecule of hydrogen and water as the only side product of the reaction. Preparation of well-defined complexes from these ligands and applications to other hydrogen transfer processes is currently underway to gain a deeper understanding on their peculiar reactivities.

\section{Aknowledgments}

CEFIPRA/IFCPAR N $\mathrm{N}^{\circ}$ 5105-4 is acknowledged for a fellowship to A.R.S. and the funding of this project. The authors wish also to acknowledge the European union and SYNFLOW consortium for a fellowship to F. J (FP-7 integrated project Synflow, NMP-20093.2-1 no. 246461.

\section{Notes and references}

1 P. G. M. Wuts, (ed) (2014) Protection for the Carbonyl Group, in Greene's Protective Groups in Organic Synthesis: Fifth Edition, John Wiley \& Sons, Inc., Hoboken, New Jersey pp, 554-685.

2 (a) S. Lüftl, P. M. Vizakh and S. Chandran, Polyoxymethylene Handbook: Structure, Properties, Applications and Their Nanocomposites, John Wiley \& Sons, Inc., Hoboken, NJ, USA 2014; (b) E. E. Falco, M. Patel and J. P. Fisher, Pharm. Res., 2008, 25, 2348.

3 E. V. Gusevskaya, J. Jiménez-Pinto and A. Börner, Chem CatChem, 2014, 6, 382.

4 (a) F. Frusteri, L. Spadaro, C. Beatrice and C. Guido, Chem. Eng. J., 2007, 134, 239; (b) A. R. Trifoli, P. S. Agachi and T. Pap, Renew. Sust. Energ. Rev., 2016, 62, 804.

5 (a) E. H. Cordes and H. G. Bull, Chem. Rev., 1974, 74, 581; (b) D. M. Clode, Chem. Rev., 1979, 79, 491; (c) F. A. J. Meskens, Synthesis, 1981, 501.

6 (a) T. Mallat and A. Baiker, Chem. Rev., 2004, 104, 3037; (b) S. Krompiec, M. Penkala, K. Szczubialka and E. Kowalska, Coord. Chem. Rev., 2012, 256, 2057; (c) K.-a Thavornprasert, M. Capron, L. Jalowiecki-Duhamel and F. Dumeignil, Catal. Sci. Technol., 2016, 6, 958.

7 Y. Yuan, H. Liu, H. Imoto, T. Shido and Y. Iwasawa, J. Catal., 2000, 195, 51;

8 (a) E. Höft, J. Dahlmann and L. Rüffer, Z. Chem., 1987, 26, 102; (b) Y. Zhang, I. J. Drake, D. N. Briggs and A. T. Bell, J. Catal., 2006, 244, 219;

9 H. Liu and E. Iglesia, J. Phys. Chem. B, 2005, 109, 2155.

10 (a) A. C. Bueno, J. A. Gonçalves and E. V. Gusevskaya, Appl. Catal., A., 2007, 329, 1; (b) A. S. Y. Chan, W. Chen, H. Wang, J. E. Rowe and T. Madey, J. Phys. Chem. B, 2004, 108, 14643

11 S. Chen, S. Wang, X. Ma and J. Gong, Chem. Commun., 2011, 47, 9345;

12 H. Zhang, Z. Zhu, Y. Wu, T. Zhao and L. Li, Green Chem., 2014, 16, 4076.

13 (a) C. Gunanathan and D. Milstein, Science 2013, 341, 1229712; (b) B. Zhao, Z. Han, K. Ding, Angew. Chem. Int. Ed., 2013, 52, 4744; (c) Q. Yang, Q. Wang and Z. Yu, Chem. Soc. Rev., 2015, 44, 2305; (d) S. Werkmeister, J. Neumann, K. Junge and M. Beller, Chem. Eur. J., 2015, 21, 12226; (e) F. Huang, Z. Liu and Z. Yu, Angew. Chem. Int. Ed., 2016, 55, 862.

14 Selected references: (a) J. Zhang, G. Leitus, Y. Ben-David and D. Milstein, J. Am. Chem. Soc., 2005, 127, 10840; (b) D. Spasyuk and D. Gusev, Organometallics, 2012, 31, 5239; (c) M. Nielsen, A. Kammer, D. Cozzula, H. Junge, S. Gladiali and M. Beller, Angew. Chem. Int. Ed., 2011, 50, 9593; (d) A. Yoshinari, A. Tazawa, S. Kuwata and T. Ikarya, Chem. Asian J., 2012, 7, 1417; (e) R. E. Rodriguez-Lugo, M. Trincado and H. Grützmacher, ChemCatChem, 2013, 5, 1079; (f) I. Dutta, A. Sarbajna, P. Pandey, S. M. Wahidur Rahaman, K. Singh and J. Bera, Organometallics, 2016, 35, 1505; $(\mathrm{g})$ Q. Wang, K. Wu and Z. Yu, Organometallics, 2016, 35, 1251.

15 S.-I. Murahashi, T. Naota, K. Ito, Y. Maeda and H. Taki, J. Org. Chem., 1987, 52, 4319.

16 (a) C. Gunanathan, L. J. W. Shimon and D. Milstein, J. Am. Chem. Soc., 2009, 131, 3146; (b) E. Kossoy, Y. Diskin-Posner, G. Leitus and D. Milstein, Adv. Synth. Catal., 2012, 354, 497.

17 Selected references: (a) K.-i. Fujita, N. Tanino and R. Yamaguchi, Org. Lett., 2007, 9, 109; (b) A. M. Royer, T. B. Rauchfuss and D. L. Gray, Organometallics, 2010, 29, 6763; (c) K. -i. Fujita, T. Yoshida, Y. Imori and R. Yamaguchi, Org. Lett., 2011, 13, 2278; (d) . Nieto, M. S. Livings, J. B. Sacci III, L. E. Reuthers, M. Zeller and E. T. Papish, Organometallics, 2011, 30, 6339 (e) R. Kawahara, K.-i. Fujita and R. Yamaguchi, Angew. Chem. Int. Ed., 2012, 51, 12790; (f) C. M. Moore and N. K. Szymczak, Chem. Commun., 2013, 49, 400; $(g)$ S. Chakraborty, P. E. Piszel, W. B. Brennessel and W. D. Jones, Organometallics, 2015, 34, 5203; (h) C. M. Moore, B. Bark and N. K. Szymczack, ACS Catal., 2016, 6, 1981; (i) J. Shi, B. Hu, D. Gong, S. Shang, G. hou and D. Chen, Dalton Trans., 2016, 45, 4828; (j) S.-M. Lu, Z. Wang, J. Li, J. Xiao and C. Li, Green Chem., 2016, DOI: 10.1039/C6GC00856A.

18 M. -N. Birkholz, N. V. Dubrovina, H. Jiao, D. Michalik, J. Holz, R. Paciello, B. Breit and A. Börner, Chem. Eur. J., $2007,13,5896$.

19 (a) F. Jiang, M. Achard, V. Dorcet, T. Roisnel and C. Bruneau, Eur. J. Inorg. Chem., 2015, 4312; (b) F. Jiang, M. Achard and C. Bruneau, Chem. Eur. J., 2015, 21, 14319.

20 (a) A. Prades, R. Corberàn, M. Poyatos and E. Peris, Chem. Eur. J., 2008, 14, 11474; (b) M. Valencia, H. Müller-Bunz, R. A. Gossage and M. Albrecht, Chem. Commun., 2016, 52, 3344; (c) N. Kalutharage and C. S. Yi, Org. Lett., 2015, 17, 1778; (d) P. Lorusso, J. Coetzee, G. R. Eastham and D. J. Cole-Hamilton, ChemCatChem, 2016, 8, 222.

21 (a) G. Stavber, M. Zupan and S. Stavber, Tetrahedron Lett., 2006, 47, 8463; (b) Y. Liu, R. Hua, H.-B. Sun and X. Qiu, Organometallics, 2005, 24, 2819; (c) S. L. Barbosa, M. Ottone, M. C. Santos, G. C. Junior, C. D. Lima, G. C. Glososki, N. P. Lopes and S. I. Klein, Catal. Comm., 2015, 68, 97. 
22 (a) D. Morton, D. J. Cole-Hamilton, I. D. Utuk, M. Paneque-Sosa and M. Lopez-Poveda, J. Chem. Soc. Dalton Trans., 1989, 489; (b) N. Sieffert, R. Réocreux, P. Lorusso, D. J. Cole-Hamilton and M. Bühl, Chem. Eur. J., 2014, 20, 4141; (c) E. P. K. Olsen, T. Singh, P. Harris, P. G. Andersson and R. Madsen, J. Am. Chem. Soc., 2015, 137, 834;

23 (a) H. Alper and F. Sibtain, J. Org. Chem., 1988, 53, 3306; (b) J.-L. Huang, X.-J. Dai and C.-J. Li, Eur. J. Org. Chem., 2013, 6496; (c) J. Yi, J. T. Miller, D. Y. Zemlyanov, R. Zhang, P. J. Dietrich, F. H. Ribeiro, S. Suslov and M. M. Abu-Omar, Angew. Chem. Int. Ed., 2014, 53, 833; (d) H. R. Diéguez, A. Lopez, V. Domingo, J. F. Arteaga, J. A. Dobado, M. M. Herrador, J. F. Quilez del Moral and A. F. Barrero, J. Am. Chem. Soc., 2010, 132, 254; (e) X.-J. Dai and C.-J. Li, J. Am. Chem. Soc., 2016, 138, 5433;

24 (a) M. E. Thibault, D. V. DiMondo, M. Jennings, P. Verardi Abdelnur, M. N. Eberlin and M. Schlaf, Green Chem., 2011, 13, 357; (b) D. DiMondo, M. E. Thibault, J. Britten and M. Schlaf, Organometallics, 2013, 32, 6541.

25 Y. Yamamoto, K. Sugawara and M. Kakeya, Inorg. Chim. Acta, 2002, 340, 21.

26 C. B. Fisher, H. Steininger, D. S. Stephenson and H. Zipse, J. Phys. Org. Chem., 2005; 18, 901. 